\title{
Civil Society Involvement in Sustainable Development Goals (SDGs) for Eliminating All Forms of Poverty Anywhere
}

\author{
Supriyatiningsih Supriyatiningsih*1, Ralph J. Lelle ${ }^{2}$, Arlina Dewi ${ }^{3}$, Sri Sundari ${ }^{4}$, \\ Dianita Sugiyo ${ }^{5}$ and Winny Setyo Nugroho ${ }^{6}$ \\ ${ }^{I}$ Obstetric and Gynecology Department, Faculty of Medicine and Health Sciences, University of \\ Muhammadiyah Yogyakarta, Indonesia \\ Ring Road Barat, Tamantirto, Kasihan, Kota Daerah Istimewa Yogyakarta 55184 \\ ${ }^{2}$ Muenster University Hospital, Germany \\ ${ }^{3}$ Magister of Hospital Management Program/ Faculty of Medicine and Health Sciences University \\ of Muhammadiyah Yogyakarta, Indonesia \\ Ring Road Barat, Tamantirto, Kasihan, Kota Daerah Istimewa Yogyakarta 55184 \\ ${ }^{4,6}$ School of Medicine, Faculty of Medicine and Health Sciences, University of Muhammadiyah \\ Yogyakarta, Indonesia \\ ${ }^{5}$ School of Nursing, Faculty of Medicine and Health Sciences, University of Muhammadiyah \\ Yogyakarta, Indonesia \\ *Corresponding author: supriyatiningsih_upi@yahoo.com
}

\begin{abstract}
Background: Since Sustainable Development Goals (SDGs) 1 are launched globally in 2015, the United Nations encourages its member countries to conduct regular and inclusive reviews of progress towards achieving SDGs at the national and sub-national level that reported through the Voluntary National Review (VNR). VNR is also developed in the context of strengthening government policies and institutions in mobilizing support from various stakeholders and is expected to become a mean of global partnership. Objectives: To capture involvement of civil society in the goverment program. Method: The method that used was online surveys through Google Forms. Surveys were disseminated through maternal and child health movement network. Result: Most respondent generally know, but they were not involved in goverment program which related to the improvement of children's nutritional status, access to drinking water and sanitation, elimination of violence against children, elimination of violence against women, knowledge of sexual and reproductive health for adolescents. Some respondents were involved, while others were do not know about the programs. Most respondents (58.6\%) claimed that women and men have not equal opportunities in education and employment. Conclusion: It is important to socialize SDGs more systematically and massively at various levels using various media. Some of the responses received also proposed ways of socialization that were considered effective.
\end{abstract}

Keywords: SDGs, Poverty, community involvement, Voluntary National Review, stakeholders

\section{INTRODUCTION}

Since Sustainable Development Goals (SDGs) 1 are launched globally in 2015, the United Nations encourages its member countries to conduct regular and inclusive reviews of progress towards achieving SDGs at the national and sub-national level that reported through the Voluntary National Review (VNR) (Gabizon, 2016). VNR report on HLPF 2017 was conducted voluntarily by 44 member countries of the UN both developing and developed countries. The preparation of VNR aimed for facilitating experience sharing, success, challenges and learning to accelerate the achievement of SDGs. VNR is also 
developed in the context of strengthening government policies and institutions in mobilizing support from various stakeholders and is expected to become a means of global partnership. The final draft of the VNR report has been assumed through the cooperation of various parties including government, community organizations, philanthropy and business, as well as academics and experts. The descriptions of the final draft of VNR include an analysis of trends and successes, challenges and how to overcome them, innovation and important efforts to achieve goals, emerging issues, and learning. The Secretariat of SDGs Indonesia through its website has opened a public consultation to receive inputs for improvements since April 5, 2017 for a period of 14 days (High-level Political Forum (HLPF), (2017)).

Given the importance of the involvement of all parties in the implementation of this TPB, the Mother and Child Health Movement (GKIA) is called to participate in providing input to this VNR draft, especially for TPB 2 (Eliminating hunger, achieving good food and nutrition for sustainable development) and TPB 17 (Strengthening the means of implementing and revitalizing global partnerships for sustainable development). The input for TPB 2 is done directly through the comments in draft document. While inputs to TPB 17 were conducted through a survey on a number of civil society related to the involvement of civil society in the goverment program so far that the results are submitted through this report.

\section{METHODOLOGY}

The survey was conducted from April 17th, 2017 at 6 PM Western Indonesia Time. Surveys are disseminated through a network of maternal and child health movements.

\section{RESULTS AND DISCUSSION}

Table 1 Proportion of respondents

\begin{tabular}{clcc}
\hline & & N & Frequency \\
\hline Gender & & \\
- & Male & 26 & $23,4 \%$ \\
$-\quad$ Female & 85 & $76,6 \%$ \\
\hline Age & & \\
$-\quad$ - 18 & 11 & $9,9 \%$ \\
$-\quad 19-25$ & 28 & $25,22 \%$ \\
$-\quad 26-40$ & 53 & $47,74 \%$ \\
$-\quad>40$ & 19 & $17,11 \%$ \\
\hline Residence & & \\
$-\quad$ Java & 79 & $71,11 \%$ \\
- Sumatera & 11 & $9,9 \%$ \\
- Papua & 1 & $0,9 \%$ \\
- Kalimantan & Sulawesi & 9 & $8,1 \%$ \\
- Bali \& Nusa Tenggara & 7 & $6,3 \%$ \\
\hline Do you think that women \& men have earned equal rights in & 4 & $3,6 \%$ \\
education and employment? & & \\
- Already & 65 & $58,6 \%$ \\
- Not yet & 46 & $41,4 \%$ \\
\hline
\end{tabular}

Most of the respondents (74.8\%) ever heard about SDGs, while $25.2 \%$ respondents did not familiar with SDGs. The largest sources of information for SDGs are from Media $(52.8 \%)$ and Organization Civil Society (48\%). Most of respondents $(75,7 \%)$ correctly answer the definition of SDGs. The rest (24.3\%) claimed does not knowing what SDGs is. Almost all respondents stated that all parties need to be involved in SDGs. Most 
respondents were generally know but not involved in the program related to the goverment improvement in nutritional status for children, access to dringking water and sanitation, elimination of violence againts children, elimination of violence againts women, knowledge of sexual and reproductive health for adolescents. Some respondents were involved in the program implementation, while few of them do not know about the programs. Most of the respondents $(58.6 \%)$ stated that women and men have not received equal opportunities in educational and employment (Figure 1).

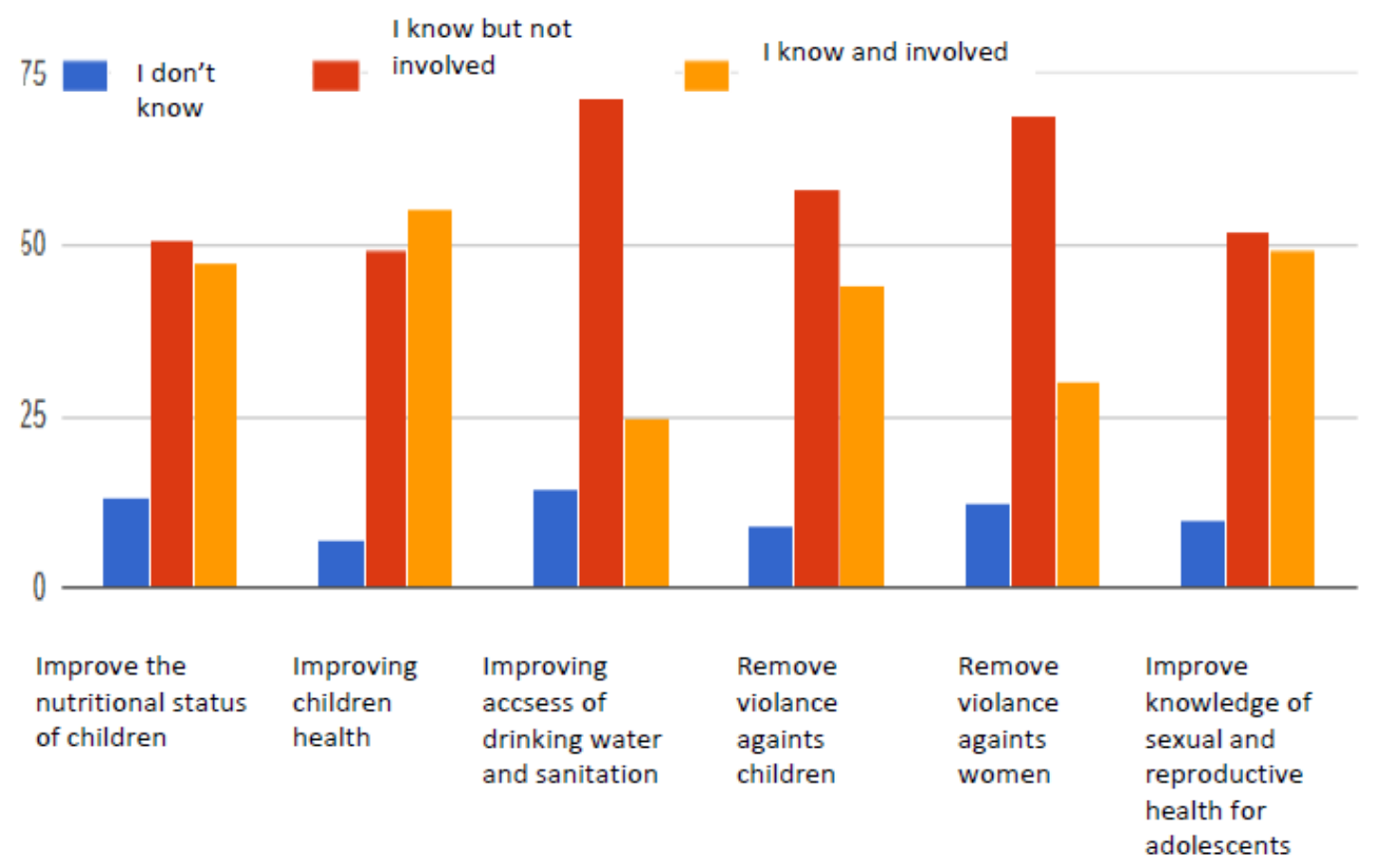

Figure 1 Goverment program that has been done in an effort and respondents involvement in the program

From the survey and the challenge of reaching TPB Goal 2 (excluding Hunger) is closely linked to the increasingly complexity of providing adequate food and nutrition for the entire population in a sustainable way. For indonesia with a large population and the available natural resources, this mainstay of food fulfillment comes primarily from domestic production. Therefore, every government in Indonesia put the achievement of self-sufficiency and stability of staple food prices become one of the priority of economic policies on food. The challenge of achieving goals without starvation can be defined on two issues; food production (supply) and food consumption (demand). Food security conditions are achieved if the fulfillment of food for the state up to the individual that is reflected from the availability of adequate food, both quantity and quality, safe, diverse, nutritious, equitable, and affordable and not contrary to the religion, beliefs and culture of society, to Able to live healthy, active, and productive in a sustainable (Food Law) (Gabizon, 2016).

In general, sustained food demand is increasing faster than the growth of domestic food production. Demand challenging are the existence of the following problems: (1) Indonesia has a large population, still growing and there are population dynamics that change the pattern of food consumption such as urbanization and increasing the proportion of women entering the labor force; (2) The existence of limited physical access to food in the form of limited access to transportation and there are isolated areas and islands and uneven economic access in the form of low income and purchasing power of some communities; (3) Changes in the pattern of food consumption of the community towards 
more diverse food patterns but not relying on the diversity of local food sources but following the diet of the population in developed countries (western diet); and low knowledge of food and nutrition, especially diets that are diverse nutritiously balanced and safe (Imdad, 2011) (Bhutta, 2008). On the other hand, food supply challenges arise, especially the increase in domestic production, are increasingly heavier, among others due to: ongoing conversion of agricultural land, the occurrence of degradation of the quality of land and water resources and competition in its use with the industrial sector and the higher occurrence of extreme climate change whose impact can decrease crop productivity and increase the risk of crop failure; and there is still a high proportion of the loss of yield and food wastage starting from the level of farming to ready to eat (food losses and waste from farm to table) that reduces the availability of food for consumption (Gabizon, 2016).

Table 2 Respondents' responses on the SDGs

\begin{tabular}{|c|c|c|c|c|c|c|}
\hline & $\begin{array}{l}\text { Not } \\
\text { important }\end{array}$ & $\begin{array}{l}\text { Slightly } \\
\text { not } \\
\text { important }\end{array}$ & Neither & $\begin{array}{l}\text { Slightly } \\
\text { important }\end{array}$ & $\begin{array}{l}\text { Quite } \\
\text { important }\end{array}$ & $\begin{array}{l}\text { Very } \\
\text { important }\end{array}$ \\
\hline $\begin{array}{l}\text { In your opinion, how } \\
\text { important is the goverment } \\
\text { program in improving the } \\
\text { nutritional status of children? }\end{array}$ & $0 \%$ & $0 \%$ & $0 \%$ & $0,9 \%$ & $8,1 \%$ & $91 \%$ \\
\hline $\begin{array}{l}\text { In your opinion, how } \\
\text { important is the goverment } \\
\text { program in improving the } \\
\text { children health? }\end{array}$ & $0 \%$ & $0 \%$ & $0 \%$ & $0 \%$ & $8,1 \%$ & $91,9 \%$ \\
\hline $\begin{array}{l}\text { In your opinion, how } \\
\text { impportant is the goverment } \\
\text { program in improving the } \\
\text { access of drinking water and } \\
\text { sanitation? }\end{array}$ & $0 \%$ & $0 \%$ & $0 \%$ & $1,8 \%$ & $8,1 \%$ & $89,2 \%$ \\
\hline $\begin{array}{l}\text { In your opinion, how } \\
\text { important is the goverment } \\
\text { program to eliminate } \\
\text { discrimination for women? } \\
\text { (ex: increased in the number of } \\
\text { women parlement member) }\end{array}$ & $0 \%$ & $0,9 \%$ & $1,8 \%$ & $10,8 \%$ & $24,3 \%$ & $62,2 \%$ \\
\hline $\begin{array}{l}\text { In your opinion, how } \\
\text { important is the goverment } \\
\text { program to eliminate violence } \\
\text { againts children? }\end{array}$ & $0 \%$ & $0 \%$ & $0 \%$ & $0 \%$ & $2,7 \%$ & $97,3 \%$ \\
\hline $\begin{array}{l}\text { In your opinion, how } \\
\text { important is the goverment } \\
\text { program to eliminate violence } \\
\text { againts women? }\end{array}$ & $0 \%$ & $0 \%$ & $0 \%$ & $0,9 \%$ & $2,7 \%$ & $96,4 \%$ \\
\hline $\begin{array}{l}\text { In your opinion, how } \\
\text { important is the goverment } \\
\text { program in increasing sexual } \\
\text { and reproductives health for } \\
\text { adolescents }\end{array}$ & $0 \%$ & $0,9 \%$ & $1,8 \%$ & $3,6 \%$ & $7,2 \%$ & $89,2 \%$ \\
\hline
\end{tabular}

The successful development of food and nutrition is the formation of healthy, active and productive Indonesian human beings. From various indicators of the nutritional status of the community presented above, it is known that the success of human development is still faced with several challenges. The main challenges faced in achieving good community nutritional status include: (1) inadequate feeding behavior of infants and children according to the WHO gold standard. It is characterized by low coverage of early breastfeeding initiation; exclusive Breastfeeding; quality, and breast milk continued for 2 
years or more. The breastfeeding problem implies high prevalence of underweight children under five. It has not achieved significant improvements in the last 10 years and is even likely to increase to $21 \%$ by 2016 , (2) the quality of nutritional improvements through cross-sectoral channels is also not optimal, although Indonesia has managed to reduce stunting rates of children under two years old (baduta) (around 2016 by $26.1 \%$ ), but this figure is still above the threshold of public health problems. Stunting is an indication of the occurrence of cognitive impairment, as well as low productivity and potential health problems in adulthood (Scrimshaw, 1968), (World Bank, 2012).

\section{How to Overcome Challenges}

To overcome these challenges, an integrated food and nutrition development approach is needed. Production and food supply policies need to be directed to provide adequate, diverse, balanced and safe nutrition, and at a price that is affordable to the purchasing power of most communities. A more supportive policy, promoting and protecting breastfeeding mothers and improving parents / caregiver skills in infant and child feeding according to gold standards also needs to be strengthened both at the central and regional levels (Kumar, Kumar, \& Vivekadhish, 2016). Steps taken to overcome these challenges include: to intensify sustainable agricultural research and development activities in an effort to create innovative agricultural technology and agricultural institutional engineering that can improve productivity, business efficiency, and product competitiveness in domestic and international markets. The second atep is encourage local governments to immediately issue a Regional Regulation on the allocation of areas for sustainable agriculture and the opening of new agricultural land that is potential food to be developed to produce food while maintaining the environmental sustainability. The third step is build and rehabilitate food agriculture infrastructure, encourage / facilitate private investment in rural agribusiness, and empower smallholders and farmer groups to improve productivity, business efficiency, and product competitiveness. Another step is increase efforts in post-harvest handling and distribution until final consumers to significantly reduce yield loss and food wastage. And the last step is to intensify socialization to various components of society on the importance of quality of food consumption and nutrition for healthy and productive active life, including the dissemination of food consumption pattern of diverse nutritious balanced and safe (B2SA) based on local food (Shrimpton, 2008).

These activities include empowering women's groups in producing, processing, and serving B2SA food from surrounding food sources for home-based meals; intensify the implementation of the First 1000 Day Life Movement (HPK) involving across sectors and various stakeholders to work together to reduce the prevalence of stunting and other forms of malnutrition; build and rehabilitate food agriculture infrastructure, encourage / facilitate private investments in food agribusiness in rural areas, and empower smallholders and farmer groups to improve productivity, business efficiency, and product competitiveness; increase efforts in post-harvest handling and distribution until final consumers to significantly reduce yield loss and food wastage; to intensify socialization to various components of the community on the importance of quality of food and nutrition for healthy and productive active life, including the socialization of food-rich and locally diverse nutritious food-based (B2SA) diverse food patterns (Kumar, Kumar, \& Vivekadhish, 2016). In this activity includes empowering women's groups in producing, processing, and serving the B2SA food from surrounding food sources for meals in the household; complete the draft Government Regulation on Food Label and Advertisement that raises the age limit on the prohibition of food advertisements for infants and children up to age 3 under World Health Assembly 2016 resolution calling 
for an end to irresponsible promotion of baby food products and children up to age 3 Indonesia is one of the countries that support this resolution; strengthening policies that support the 10 Steps of Breastfeeding Success (10 LMKM) through the Maternity Hospital program and aligning them with other flagship programs such as Maternity and Infant Hospital which are similar in nature but not exactly the same as the Baby Friendly Hospital program (Buse, K \& Hawkes, S, 2015)

\section{Innovation and Essential Achievements of Goals}

Various innovations and important efforts related to the achievement of TPB Goal 2 Without Famine has been created and implemented by the government with the development of food and nutrition stakeholders. Some important innovations include: (1) Presidential Regulation (Presidential Regulation) no. 42 of 2013 on the National Movement for the Acceleration of Nutrition Improvement on May 24, 2013 regulates nutrition improvement policy focusing on the first 1000 days of life (HPK). This policy integrates health services, particularly maternal, child and disease-related health through a cross-sectoral approach involving stakeholders such as businesses, civil society, development partners, and professional organizations, as well as academics. Besides, it also regulates the implementation guidelines for the planning of 1000 HPK at national and regional levels (Kumar, Kumar, \& Vivekadhish, 2016). The scheme of the 1000 HPK movement approach as in the figure below:

\section{HUMAN RESOURCES QUALIFY AND COMPETITIVE}

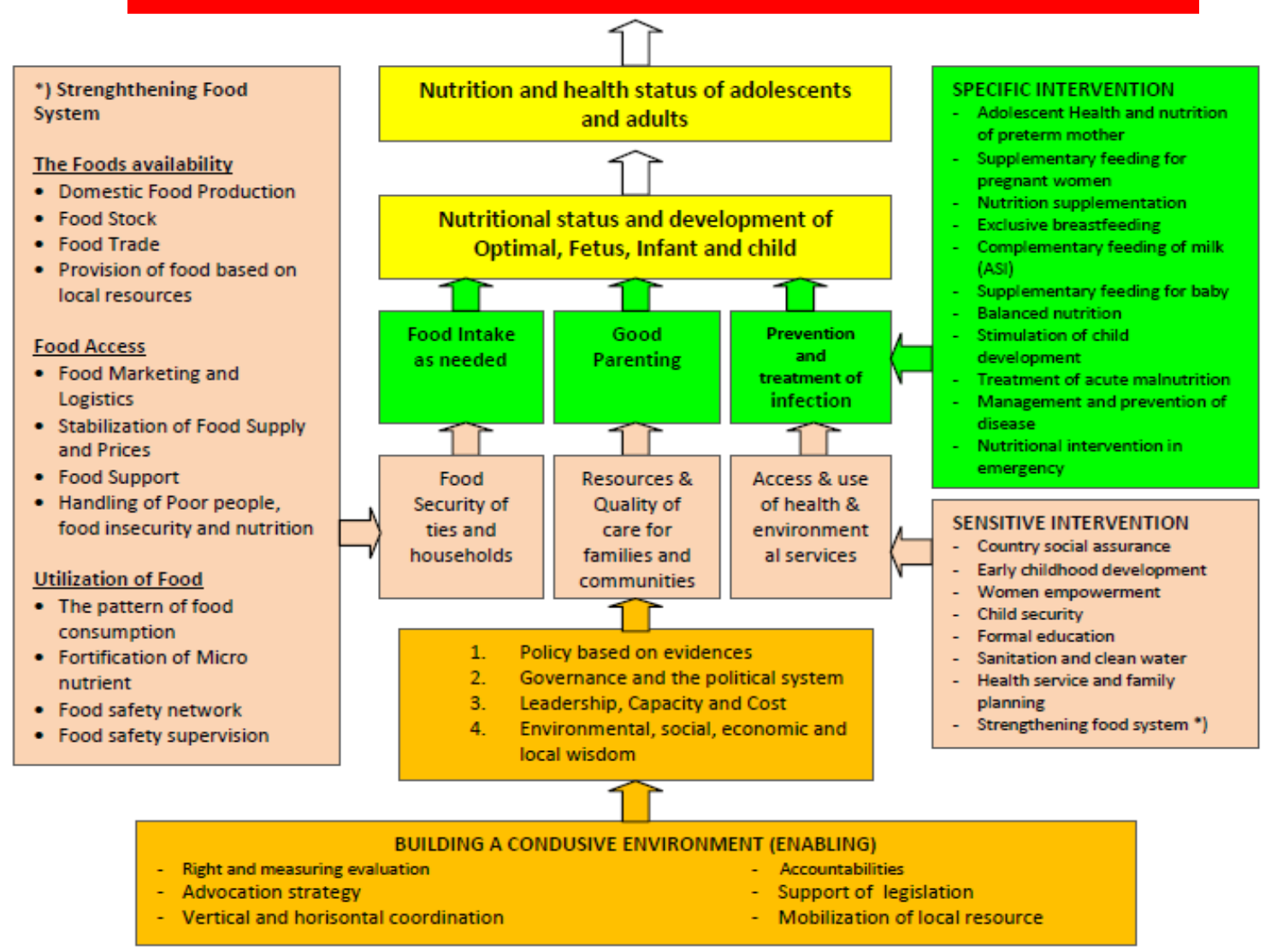

Figure 2 Scheme of the 1000 HPK movement approach

Source: Modified from Lancet, 2013: Executive summary of The Lancet Maternal and Child Nutrition Series 
Participation Indonesia as one of the first countries of 59 Countries in SUN Global, and Indonesia has implemented and developed the SUN platform, which is advocating improved nutrition to the top leaders, increasing stakeholder participation (Government, CSO, professional and academic organizations and development partners), ensuring coherent policy and the legal framework of the program, aligning the program according to the SUN Movement program framework, and identifying sources of financing (Kumar, Kumar, \& Vivekadhish, 2016). (3) Currently, a Presidential Decree on Food and Nutrition Strategic Policy (KS-PG) is set up which will guide the development of food and nutrition stakeholders at the central and regional levels in integrating food and nutrition development to achieve food sovereignty, food security and nutrition, And accelerate community nutrition improvement. Based on the 2008 Lancet Maternal and Child Undernutrition Series similarly recommended zinc supplementation as an effective intervention to reduce stunting (Bhutta, Ahmed, \& Black, 2008).

Previously Bappenas has published the National Food and Nutrition Action Plan (RAN-PG) or 2005-2010; 2011-2015 and 2015-2019, followed by the formulation of Regional Food and Nutrition Action Plans (RAD-PG) at the provincial and district / city levels. It has also been drafted by the Food Security Council (DKP) General Policy for Food Security (KUKP) for two periods of five years. Program of integration of nutritionspecific interventions and sensitive interventions such as sanitation (National Community Empowerment Program (PNPM) Generation Healthy and Smart, Achievement PKH). Government Regulation (PP) No. 33 of 2012 on Exclusive Breastfeeding which becomes the legal umbrella in supporting the fulfillment of the right of infant for the best nutrition and protecting the mother in giving exclusive breastfeeding (PP, 2012).

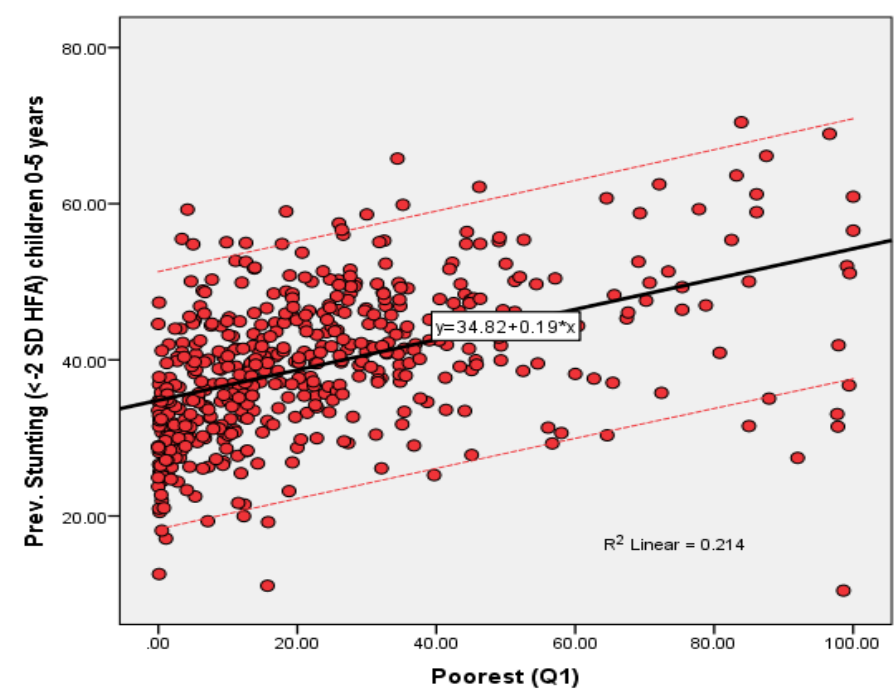

Figure 3 The Linkage Between Underweight and Stunting with Poverty

Looking at the linkage of poverty to nutritional status it is necessary to see its relevance also with education and environmental conditions (Trihono, Atmarita, Hapsari, 2015). Education affects behavior (parenting and eating patterns) which in turn affects the nutritional status of children, the lower the education the nutritional status of children will tend to be worse. Another is good environmental health conditions (good coverage of sanitation coverage and good water coverage), will affect the nutritional status of children better, as presented in the following figure: 


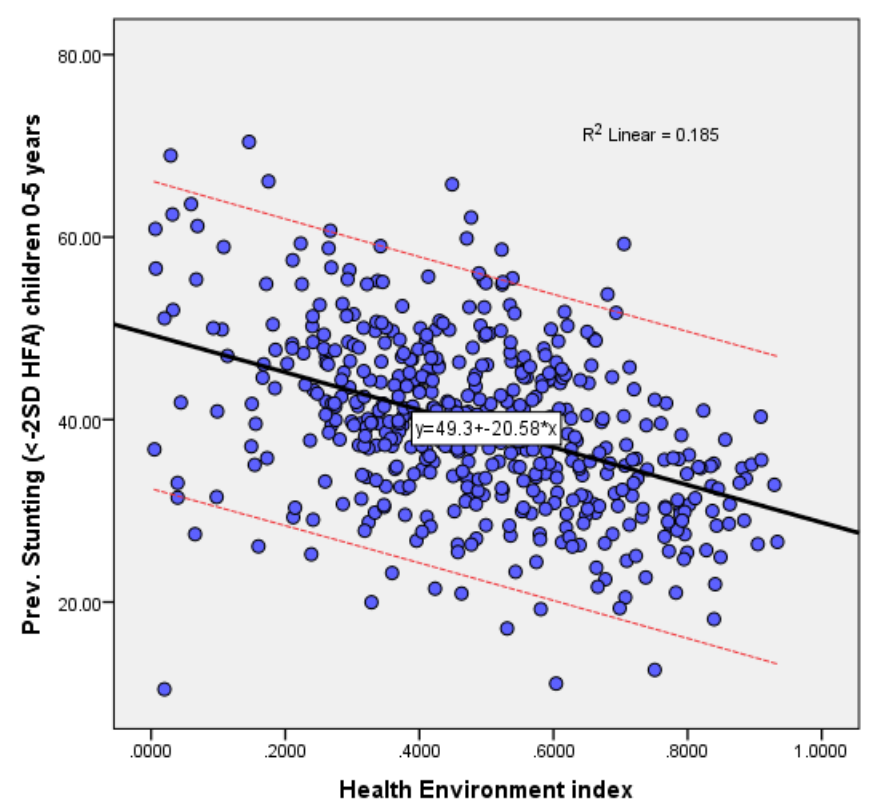

Figure 4 Linkages Between Underweight and Stunting with Education Level and Environmental Conditions

\section{CONCLUSION}

The conclusion is remind each other in the term of the need to socialize SDGs more systematically and massively at various levels using various media. Some of the responses received also proposed ways of socialization that were considered effective. The majority of respondents reminded of the need to socialize TPB / SDGs more systematically and massively at various levels using various media. Some of the responses received also suggested the dissemination of ways of socialization that are considered effective. The involvement of civil society with regard to SDGs is also a prominent suggestion given by the respondents. Suggestions for community engagement is vary, starting with the importance of access to information. This chance will lead the community to be able to participate on community engagement. Planning, monitoring, and implementation are the way how the community could engange in the program. Various suggestions in the implementation of future SDGs were submitted by the respondents, including: more equitable program socialization, community involvement in program implementation, mentoring, strengthening policies and regulations.

\section{ACKNOWLEDGEMENT}

Specific recognition has to be given to the team for their great support of this work. Especially for Prof. Dr. Med. Ralph J. Lelle, MD,PhD,MIAC, Dr. dr. Arlina Dewi, M.Kes, Dr.dr. Sri Sundari, M.Kes, Dianita Sugiyo, S.Kep., Ns.,MHID.,HNC, Winny Setyonugroho, S.Ked.,MT, PhD for their dedicated work in collecting and collaborating data used in this article as a part of the objective of our research for this surveys. 


\section{REFERENCES}

Bhutta, ZA, Ahmed, T., \& Black, RE, (2008). Maternal and Child Undernutrition 3: What Works? Interventions for Maternal and Child Undernutrition and Survival. Lancet: 371: 417-40.

Buse, K \& Hawkes, S. (2015). Health in the sustainable development goals: ready for a paradigm shift?, Globalization and Health, https://doi.org/10.1186/s12992-015-0098-8

Gabizon, S. (2016). Women's movements' engagement in the SDGs: lessons learned from the Women's Major Group, Gender \& Development, 24(1), 99-110.

High-level Political Forum (HLPF), (2017). UN Economic and Social Council (ECOSOC),New York

Imdad A, Bhutta ZA. (2011). Effect of preventive zinc supplementation on linear growth in children under 5 years of age in developing countries: a meta-analysis of studies for input to the lives saved tool. BMC Public Health, 11 (suppl 3); S22.

Kumar, S, Kumar, N, \& Vivekadhish, S. (2016). Millennium Development Goals (MDGs) to Sustainable Development Goals (SDGs): Addressing Unfinished Agenda and Strengthening Sustainable Development and Partnership, Indian Journal of Community Medicine, 41(1), 1-4.

Peraturan Presiden No.42 tahun 2013 tentang Gerakan Nasional Percepatan Perbaikan Gizi.

Peraturan Pemerintah (PP) No.33 tahun 2012 tentang Pemberian ASI Ekslusif.

Scrimshaw NS, Taylor CE, Gordon JE. (1968). Effect of Infection on nutritional status. In Scrimshaw NS, Taylor CE, Gordon JE, eds. Interaction of nutrition and infection. Geneva: World Health Organization, 3-329 (WHO monograph series no.57).

Sénit, C, Biermann, F, \& Kalfagianni, A. (2016). The Representativeness of Global Deliberation: A Critical Assessment of Civil Society Consultations for Sustainable Development, Global Policy, 8(1), 62-72.

Shrimpton R, Shankar AH. Zinc Deficiency. (2008). In: Nutrition and Health in Developing Countries, 2nd ed. (Eds. RD Semba, MW Bloem). Totowa, NJ: Humana Press.

Trihono, Atmarita, Hapsari, D, (2015). Pendek (Stunting) di Indonesia, masalah dan solusinya, Badan Penelitian dan Pengembangan Kesehatan (Balitbangkes). 